\title{
NITRIC OXIDE METABOLISM FEATURES UNDER CONDITIONS OF EXPERIMENTAL INFECTED RADIATION-INDUCED SKIN INJURIES DEVELOPMENT AND THEIR TREATMENT WITH PHOTODYNAMIC THERAPY
}

D0I: $10.36740 /$ WLek202008112

\author{
Mykola V. Krasnoselskyi', Elena S. Pushkar', Larisa I. Simonova-Pushkar' ${ }^{1}$, Mykhailo S. Myroshnychenko² \\ 'STATE ORGANIZATION «GRYGORIEV INSTITUTE FOR MEDICAL RADIOLOGY AND ONCOLOGY OF THE NATIONAL ACADEMY OF MEDICAL SCIENCES OF \\ UKRAINE», KHARKIV, UKRAINE \\ 2KHARKIV NATIONAL MEDICAL UNIVERSITY, KHARKIV, UKRAINE
}

\begin{abstract}
The aim: To follow-up nitric oxide content values in rat serum at the development of Staphylococcus aureus infected radiation skin injuries and their photodynamic therapy. Materials and methods: Eighty WAG male rats were studied in an experiment. Four groups were identified for evaluation. Group 1 included unaffected intact rats $(\mathrm{n}=20)$. Group 2 involved rats $(n=20)$ with a modeled radiation-induced ulcer of the skin. The rats $(n=20)$ with a modeled radiation-induced skin ulcer followed by infecting with Staphylococcus aureus were referred to group 3. Group 4 included rats $(n=20)$ with Staphylococcus aureus infected radiation skin ulcer exposed to photodynamic therapy. Rats of groups 1-4 were sampled for biochemical blood examination on days 7, 14, 21, 30 and 45. Total nitric oxide metabolites (nitrites and nitrates) were measured according to V.A. Metelskaya et al. method.

Results: Infectious agent (Staphylococcus aureus) present in skin ulcer impairs nitric oxide metabolism in rat blood serum that manifested in decreased total nitric oxide metabolites content on day 7 , followed by its increase within days 14 to 45 . While photodynamic therapy exposed on the Staphylococcus aureus infected radiation skin ulcer, total nitric oxide metabolites in blood serum had increased by day 7, but days 14 to 45 level was compliant with physiological norm.

Conclusions: Infecting radiation skin ulcers with Staphylococcus aureus causes impaired nitric oxide metabolism, while photodynamic therapy helps to normalize the metabolism of the above-mentioned chemical compound that can improve healing of radiation skin ulcers.
\end{abstract}

KEY WORDS: radiation ulcer of the skin, Staphylococcus aureus, nitric oxide, photodynamic therapy

Wiad Lek. 2020;73(8):1655-1658

\section{INTRODUCTION}

Ionising radiation sources which fail to comply with safety rules in various industrial sectors, and those applied in medicine for irradiating patients with the purpose of diagnosis or therapy as well, can cause systemic functional disorders or local radiation injuries in the human body [1]. The severity of radiation injuries depends on the absorbed dose of ionizing radiation and grows with its increase [2].

Local radiation damage means complex morphological and functional changes in tissues that result from the ionizing radiation exposure to a relatively small area of the body [3]. Common local radiation injuries includelesions of the skin and underlying tissues, which, as a rule, appear as an undesirable effect or complication resulting from radiation therapy. The medical community has been focusing on these radiation-induced injuries for many years [3] searching for optimal, effective preventive, therapeutic and diagnostic strategies [4]. Radiation injuries of the skin and underlying soft tissues are known to develop in $95 \%$ of patients receiving radiation therapy [5].
Radiation-induced skin injures are often assessed as acute and chronic and classified on a scale of 1-4 on the basis of the Common Terminology Criteria for Adverse Events v3.0. Grade 1 changes include dry desquamation with generalized erythema. Grade 2 changes include brisk erythema or patchy moist desquamation. When the cumulative radiation dose reaches $40 \mathrm{~Gy}$ or higher, moist desquamation occurs at the folds of the skin. Grade 3 changes include extensive moist desquamation outside of the skin folds. Grade 4 changes include ulcers, bleeding and skin necrosis. The chronic radiation-induced reactions include chronic ulcerations and wounds, fibrosis, telangiectasias, secondary skin cancers and radiation-induced keratoses [4]. Among the local radiation injuries to the skin and underlying soft tissues, as reported by many authors, non-healing radiation ulcers are the most frequent [6].

Recently, much attention is being focused on the study of the contribution of nitric oxide (NO), which is one of the important regulators of the human body activity, consid- 
ering its wide range of diverse functions $[7,8]$. NO plays a critical role in all phases of wound healing [9].

Endothelial NO provides adequate vasodilation, anti-aggregatory activity, stimulates angiogenesis, modulates the cytokine cascade, and activates cell proliferation. NO acts as a chemotactic factor for fibroblasts, that results in collagenogenesis activation. Besides, NO exhibits an antimicrobial effect, activating phagocytosis, inhibits the development of radical oxidative reactions, and accelerates wound epithelization $[10,11]$.

Large amounts of NO formed in the wound under the influence of inducible NO-synthase can bind to free oxygen radicals and yield cytotoxic peroxynitrite. The latter, in its turn, suppresses the activity of mitochondrial enzymes, causes energy destabilization, alteration and mutation of cellular elements and the development of hemodynamic disturbances, which, as a result, worsen wound healing [10].

Our previous experimental studies have demonstrated that radiation skin ulcers are accompanied by an increased content of stable NO metabolites in serum [12].

Exposure to ionizing radiation is known to result in the altered microbial landscape of integument and its colonization by various infectious agents, including Staphylococcus aureus [13]. In the available national and foreign literature, we identified no studies aimed at investigation of $\mathrm{NO}$ metabolism features revealed in the development of either radiation-induced skin ulcers infected with Staphylococcus aureus or skin radiation ulcers infected with Staphylococcus aureus under the influence of photodynamic therapy, which, as it has been shown by our previous studies, is effective in wound healing [14].

\section{THE AIM}

The aim of the study was to follow-up the values of NO content in rat serum with the development of the Staphylococcus aureus infected radiation-induced skin ulcers and their photodynamic therapy.

\section{MATERIALS AND METHODS}

The study was approved by the Ethics Commission of State Organization «Grygoriev Institute for Medical Radiology and Oncology of the National Academy of Medical Sciences of Ukraine». Eighty WAG male rats weighing 180-200 gram were studied in an experiment. For evaluation, we divided the animals into four groups. Group 1 included intact rats $(n=20)$, unaffected by any exposure. Group 2 involved rats $(n=20)$ with a modeled radiation-induced ulcer of the skin. The rats $(n=20)$ with a modeled radiation-induced skin ulcer followed by its infection with Staphylococcus aureus were referred to group 3. Group 4 included rats $(\mathrm{n}=20)$ with Staphylococcus aureus infected radiation skin ulcer exposed to photodynamic therapy.

In groups 2-4, a radiation ulcer was obtained by local irradiation of a skin site on the external surface of the rat thigh at a dose of 85.0 Gy using the TUR-60 X-ray apparatus (Germany). The X-rays were generated under the voltage of $50 \mathrm{kV}$, anode current of $10 \mathrm{~mA}$, aluminium filter with a thickness of $0.6 \mathrm{~mm}$, effective energy of $18 \mathrm{keV}$.

In groups 3 and 4 , on day 7 after local irradiation of the outer area of the rat thigh, with the appearance of the first signs of radiation ulcer, it was infected with a Staphylococcus aureus (ATCC 25923) bacterial strain.

Photodynamic therapy in group 4 was performed 24 hours after infection, with red light emitted using Barva-LED/630 (Ukraine). The photon radiation power was of $25 \mathrm{~mW}$, the wavelength of 630-650 nm, the exposure time of $30 \mathrm{~min}$, and the energy dose per session was $45 \mathrm{~J} /$ $\mathrm{cm}^{2}$. Methylene blue $1.0 \%$ aqueous solution was used as a photosensitizer.

Blood sampling in rats of all groups for biochemical studies was performed on days 7, 14,21, 30 and 45 . The content of total NO metabolites (nitrites and nitrates) was determined using V. A. Metelskaya et al. method [15].

Statistical analysis of the numerical values obtained in groups was performed using the software package STATISTICA 10.0. The average values of the parameters in groups were compared using parametric and nonparametric methods. The significance of the differences between the average values of the parameters in the groups was taken at a significance level of $\mathrm{p}<0.05$.

\section{RESULTS AND DISCUSSION}

NO is known to be an unstable and short-living compound; therefore, many scientists suggest to assess its level in tissues by the content of stable nitrogen metabolites, such as nitrates and nitrites [15].

When analyzing the data obtained (table 1, fig. 1), we observed that in group 2, compared to group 1, no changes $(p>0.05)$ in the level of NO metabolites were registered on day 7 , but this value increased $(\mathrm{p}<0.05)$ dramatically (on average by $49.2 \%$ ) from day 14 to day 45 , and the maximum value of this parameter was seen on day 45 . In our previous studies [12] we also revealed an increase of NO content in blood serum during the development of radiation ulcers of the skin.

In group 3, compared to group 1 , the level of $\mathrm{NO}$ metabolites on day 7 decreased significantly $(\mathrm{p}<0.05)$ by $20.8 \%$, and from day 14 to 45 it increased dramatically $(\mathrm{p}<0.05)$, on average by $58.3 \%$ (table 1 , fig. 1$)$. In group 4 , versus group 1, the value of NO metabolites on day 7 was significantly $(\mathrm{p}<0.05)$ higher (by $39.7 \%)$, and from day 14 to day 45 no significant changes $(p>0.05)$ were registered (table 1, fig. 1).

The revealed excessive production of NO metabolites in groups 2 and 3 from day 14 to day 45 , in group 4 on day 7 may be due to an increase in the number of NO-producing cells (leukocytes, macrophages etc.) in the pathological site and activation of their morphofunctional conditions, which is a response to alteration due to the exposure to radiation (in groups 2-4) and an infectious agent present (in groups 3 and 4 ) with the subsequent death of these cellular elements and the release of a great amount of biologically active substances including NO. 


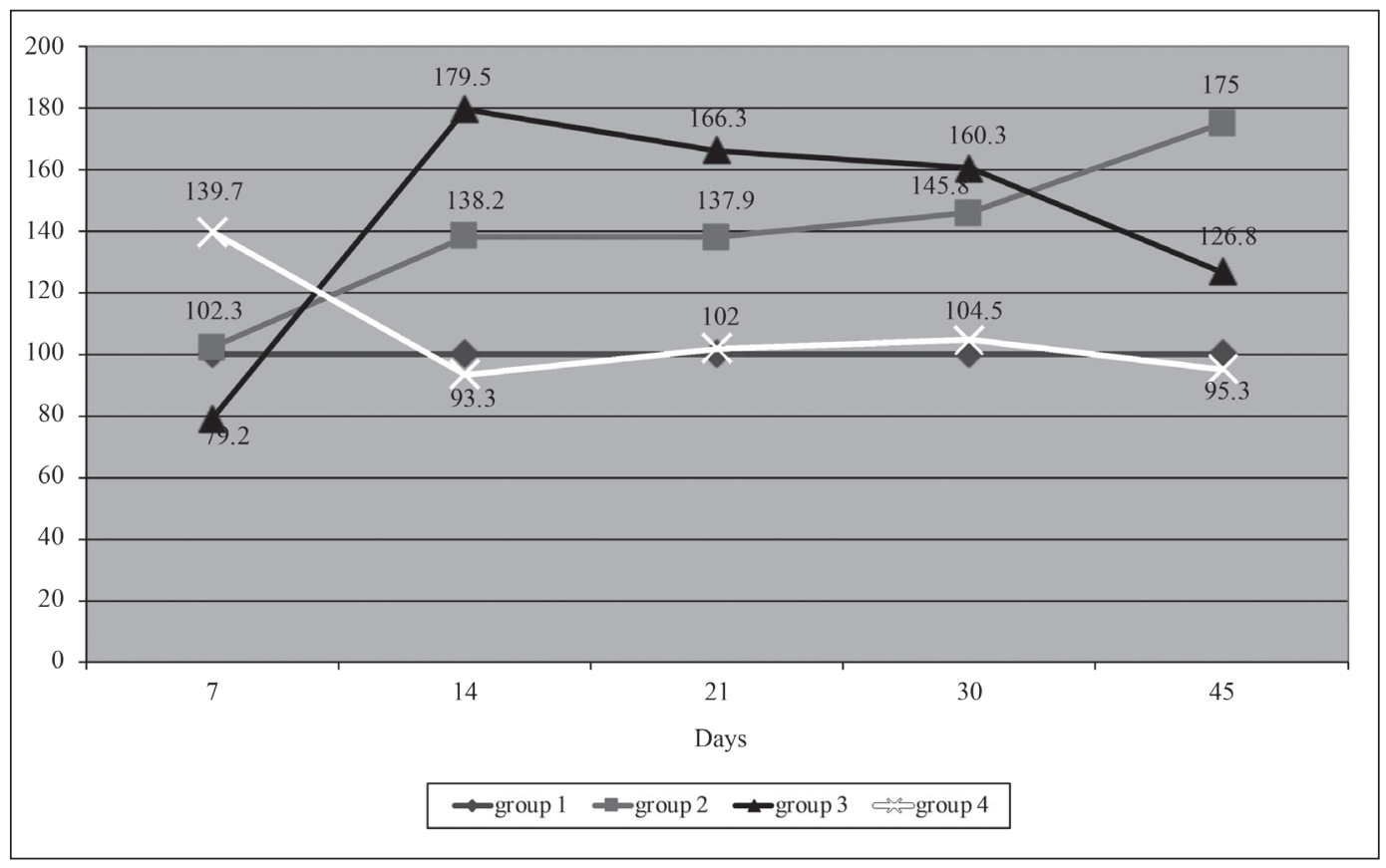

Fig.1. The per cent change in the blood serum content of NO metabolites in rats of groups 2-4 compared to the physiological norm (group 1 value).

Table 1. The content of NO metabolites ( $\mu \mathrm{mol} / \mathrm{L}$ ) in groups 1-4

\begin{tabular}{|c|c|c|c|c|c|}
\hline \multirow{2}{*}{ Group } & \multicolumn{5}{|c|}{ Observation period, day } \\
\hline & 7 & 14 & 21 & 30 & 45 \\
\hline 1 & & & $44.8 \pm 2.1$ & & \\
\hline 2 & $\begin{array}{c}45.9 \pm 2.4 \\
p_{1}>0.05\end{array}$ & $\begin{array}{l}61.9 \pm 3.7 \\
p_{1}<0.05\end{array}$ & $\begin{array}{l}61.8 \pm 2.6 \\
p_{1}<0.05\end{array}$ & $\begin{array}{c}65.3 \pm 4.9 \\
p_{1}<0.05\end{array}$ & $\begin{array}{c}78.4 \pm 1.5 \\
p_{1}<0.05\end{array}$ \\
\hline 3 & $\begin{array}{c}35.5 \pm 2.0 \\
\mathrm{p}_{1}<0.05 \\
\mathrm{p}_{2}<0.05\end{array}$ & $\begin{array}{c}80.4 \pm 1.2 \\
p_{1}<0.05 \\
p_{2}<0.05\end{array}$ & $\begin{array}{c}74.5 \pm 1.0 \\
\mathrm{p}_{1}<0.05 \\
\mathrm{p}_{2}<0.05\end{array}$ & $\begin{array}{l}71.8 \pm 4.5 \\
\mathrm{p}_{1}<0.05 \\
\mathrm{p}_{2}<0.05\end{array}$ & $\begin{array}{c}56.8 \pm 5.2 \\
\mathrm{p}_{1}<0.05 \\
\mathrm{p}_{2}<0.05\end{array}$ \\
\hline 4 & $\begin{array}{l}62.6 \pm 3.5 \\
\mathrm{p}_{1}<0.05 \\
\mathrm{p}_{2}<0.05 \\
\mathrm{p}_{3}<0.05\end{array}$ & $\begin{array}{l}41.8 \pm 1.7 \\
\mathrm{p}_{1}>0.05 \\
\mathrm{p}_{2}<0.05 \\
\mathrm{p}_{3}<0.05\end{array}$ & $\begin{array}{l}45.7 \pm 0.7 \\
\mathrm{p}_{1}>0.05 \\
\mathrm{p}_{2}<0.05 \\
\mathrm{p}_{3}<0.05\end{array}$ & $\begin{array}{c}46.8 \pm 3.1 \\
\mathrm{p}_{1}>0.05 \\
\mathrm{p}_{2}<0.05 \\
\mathrm{p}_{3}<0.05\end{array}$ & $\begin{array}{l}42.7 \pm 2.2 \\
\mathrm{p}_{1}>0.05 \\
\mathrm{p}_{2}<0.05 \\
\mathrm{p}_{3}<0.05\end{array}$ \\
\hline
\end{tabular}

Note: $p_{1}$ - the significance of the differences compared to the value of group $1 ; p_{2}$ - the significance of the differences compared to the value of group 2 ; $\mathrm{p}_{3}$ - the significance of the differences compared to the value of group 3 .

An infectious agent present in the skin radiation ulcer significantly changes the features of NO production, as evidenced by a comparative analysis of the NO metabolite level in group 3 compared with group 2 (table 1). Thus, Staphylococcus aureus present in radiation-induced ulcer of the skin caused the death of NO-producing cells on day 7 , manifested by a decreased $(\mathrm{p}<0.05)$ NO metabolite level, and from day 14 to day 30 it resulted in an increased number of these cell elements, which was manifested by an increased $(p<0.05)$ level of NO metabolites focused on the rapid, complete elimination of the infectious agent from the affected site. On day 45 , in group 3, compared with group 2 , the level of $\mathrm{NO}$ metabolites in animal blood serum was significantly $(\mathrm{p}<0.05)$ lower.

Excessive production of $\mathrm{NO}$ metabolites in groups 2 and 3 can be formed under the influence of both endothelial $\mathrm{NO}$-synthase and inducible NO-synthase, having either positive or negative values. It is known that prolonged increase of NO level results in a significant deterioration in the overall free radical status in the body, contributes to the formation of peroxynitrite, which is an extremely aggressive radical that can damage the cellular DNA, cause mutations and death of microbes, and the cellular elements of radiation ulcers as well, that in its turn complicates and inhibits regenerative processes in the affected site [16].

While the photodynamic therapy, the level of NO metabolites on day 7 in group 4 increased compared to group 3 value $(\mathrm{p}<0.05)$, that indicated a pronounced antimicrobial effect, and decreased for the period from day 7 to day $45(p<0.05)$ (table 1). Thus, photodynamic therapy aids normalizing of NO metabolism, which, combined with its other positive effects described earlier in our studies and the works of other scientists [12], will stimulate and activate the healing processes of radiation ulcers.

\section{CONCLUSIONS}

1. The presence of an infectious agent (Staphylococcus aureus) in the skin ulcer causes disordered nitric oxide metabolism 
in blood serum of rats that is manifested on day 7 by a decreased content of nitric oxide total metabolites with its subsequent increase for the period from day 14 to 45 .

2. During the photodynamic therapy exposed to a Staphylococcus aureus infected skin radiation ulcer, the content of total nitric oxide metabolites in blood serum increased by day 7 , and from day 14 to day 45 it corresponded to the physiological norm.

3. Normalizing of nitric oxide metabolism registered while the photodynamic therapy can contribute to the improvement of the healing processes of skin radiation ulcers.

Promising further research is a morphological study aiming to describe the features of the morphological and functional state of radiation-induced skin ulcers infected with Staphylococcus aureus under exposure to photodynamic therapy.

\section{REFERENCES}

1. Temnov AA, Astrelina TA, Rogov KA et al. Issledovaniye vliyaniya faktorov konditsionnoy sredy, poluchennoy pri kul'tivirovanii mezenkhimal'nykh stvolovykh kletok kostnogo mozga, na techeniye tyazhelykh mestnykh luchevykh porazheniy kozhi u krys. [Investigation of the influence of the conditioning medium factors obtained during the cultivation of bone marrow mesenchymal stem cells on the course of severe local radiation injuries of skin in rats]. Medical radiology and radiation safety. 2018;63(1):35-39. (Ru)

2. Kriachok IA, Ulyanchenko KO, Tytorenko IB etal. Otdalennyye oslozhneniya luchevoy terapii u bol'nykh so zlokachestvennymi novoobrazovaniyami. [Remote complications of radiation therapy in patients with malignant neoplasms]. Clinical oncology. 2017;4(28):59-62. (Ru)

3. Barabanova AV.Mestnyyeluchevyye porazheniya kozhi. [Local radiation injury skin]. Medical radiology and radiation safety. 2010; 55(5):79-84. (Ru)

4. Wei J, Meng L, Hou X et al. Radiation-induced skin reactions: mechanism and treatment. Cancer management and research. 2019;11:167-177.

5. Khalin I, Kocherga G. Arginine glutamate improves healing of radiationinduced skin ulcers in guinea pigs. International journal of radiation biology. 2013;1-8. D0I: 10.3109/09553002.2013.817698

6. Topuzov EE, Agishev TT, Bozhok AA et al. Kliniko-morfologicheskaya kharakteristika povrezhdeniy kozhi i podkozhno-zhirovoy kletchatki posle khirurgicheskogo lecheniya i luchevoy terapii u bol'nykh rakom molochnoy zhelezy (obzor literatury). [Clinical and morphological characteristics of skin and subcutaneous fat damage after surgical treatment and radiation therapy in patients with breast cancer (literature review)]. Tumors of female reproductive system. 2017;13(1):25-33. (Ru)

7. Antosova M, Plevkova J, Strapkova A et al. Nitric oxide - important messenger in human body. Open journal of molecular and integrative physiology. 2012;2:98-106.

8. Osipenko A. Rol sistemy oksida azota v protsessakh adaptatsii organizma $k$ fizicheskim nagruzkam. [The role of the nitric oxide system in the processes of adaptation of the body to physical activity]. Science in Olympic Sport. 2014;1:23-30. (Ru)

9. Saidkhani V, Asadizaker M, Khodayar MJ et al. The effect of nitric oxide releasing cream on healing pressure ulcers. Iranian journal of nursing and midwifery research. 2016;21:322-330.

10. Smirnov AV, Panshin NG, Slietsans AA et al. Rol N0-sistemy v morfogeneze zazhivleniya kozhnykh ran pri sakharnom diabete. [The role of NO-system in the morphogenesis of skin wound healing in diabetes mellitus]. Volgograd Journal of Medical Research. 2014;4:1013. (In Ru)
11. Moskalenko VI, Chomaev AA, Moskalenko BB et al. Oksid azota i angiogenez. [Nitric oxide and angiogenesis]. Moscow surgical journal. 2012;24(2):27-32. (Ru)

12. Simonova LI, Hertman VZ, Pushkar OS et al. Vliyaniye fotodinamicheskoy terapii na endogennyye antimikrobnyye mekhanizmy pri lechenii infitsirovannykh luchevykh povrezhdeniy kozhi. [Photodynamic therapy impact on endogenous antimicrobial mechanisms in treatment of infected radiation skin injuries]. Ukrainian journal of radiology. 2018;26(4):239-244. (Ru)

13. Simonova-Pushkar LI, Sklyar NI, Gertman VZ et al. Osobennosti mikrobiotsenoza kozhi laboratornykh zhivotnykh posle vozdeystviya ioniziruyushchey radiatsii. [Peculiarities of skin microbiocenosis of the laboratory animals exposed to ionizing radiation]. Ukrainian journal of radiology. 2015;23(1):23-29. (Ru)

14. Krasnoselskiy NV, Simonova LI, Gertman VZ et al. Vliyaniye fotodinamicheskoy terapii na zazhivleniye luchevoy yazvy kozhi, infitsirovannoy Pseudomonas aeruginosa. [Photodynamic therapy effect on healing of radiation skin ulcer infected with Pseudomonas aeruginosa]. Problems of radiation medicine and radiobiology. 2017;22:202-207. (Ru)

15. Metelskaya VA, Gumanova NG. Skrining-metod opredeleniya urovnya metabolitov oksida azota v syvorotke. [Screening-method for nitric oxide metabolites determination in human serum]. Klinicheskaya laboratornaya diagnostika. 2005;6:15-18. (Ru)

16. Kurahashi T, Fujii J. Roles of antioxidative enzymes in wound healing. Journal of developmental biology. 2015;3:57-70. D0I:10.3390/ jdb3020057

\section{ORCHID and contibutionship:}

Mykola V. Krasnoselskyi - 0000-0001-5329-5533 A,C,E

Elena S. Pushkar - 0000-0001-9028-5422 A,D,E,F

Larisa I. Simonova-Pushkar - 0000-0001-6136-3030 A,B,D

Mykhailo S. Myroshnychenko - 0000-0002-6920-8374 ${ }^{B, C, F}$

\section{Conflict of interest:}

The Authors declare no conflict of interest.

\section{CORRESPONDING AUTHOR}

Mykhailo S. Myroshnychenko

Kharkiv National Medical University, Pathological Anatomy Department str. Svetlaya27A, apt. 70, 61129, Kharkiv, Ukraine

tel: +380501699763

e-mail:msmyroshnychenko@ukr.net

Received: 19.03 .2019

Accepted:01.07.2020

A - Work concept and design, B - Data collection and analysis, C - Responsibility for statistical analysis, D-Writing the article, $\mathbf{E}$-Critical review, $\mathbf{F}$ - Final approval of the article 